\title{
Novel surgical extrication of penile constricting metal ring: A case report
}

\author{
Abimbola Olaniyi Olajide, Amogu Kalu Eziyi, \\ Folakemi Olajumoke Olajide, Babatunde Kazeem Beyioku
}

\begin{abstract}
Introduction: Penile entrapment with strangulation is a unique clinical entity which has remained a challenge because of lack of standard treatment modality. Treatment of reported cases has been based on an individual physicians approach depending upon the circumstances and facilities available. Some of these are cumbersome and some involve use of non-medical facilities. We report a novel simple surgical approach used in the management of a case of penile entrapment. Case Report: A 16-year-old male adolescent presented with four days history of entrapment of his penile shaft in a hard steel metal ring. There was associated swelling of penile shaft distal to the ring with progressive diminution of urine stream. All initial attempts for removing mettalic ring were abortive till surgical degloving of penile shaft was done in the operating room with immediate reduction of swelling and removal of constricting ring intact. There was no postoperative complication and outcome was satisfactory. Conclusion: Constricting device on a penile shaft can be removed by a simple surgical technique
\end{abstract}

Abimbola Olaniyi Olajide ${ }^{1}$, Amogu Kalu Eziyi ${ }^{1}$, Folakemi Olajumoke Olajide ${ }^{2}$, Babatunde Kazeem Beyioku ${ }^{3}$

Affiliations: ${ }^{1}$ Senior Lecturer, Department of Surgery, Ladoke Akintola University of Technology, Ogbomoso, Oyo State, Nigeria; '2Lecturer 1, Department of Community Health, Obafemi Awolowo University, Ile-Ife, Osun State, Nigeria; ${ }^{3}$ Resident Doctor, Department of Surgery, Ladoke Akintola University of Technology Teaching Hospital, Osogbo, Osun State, Nigeria.

Corresponding Author: Dr. Abimbola O. Olajide, Department of Surgery, Ladoke Akintola University of Technology Teaching Hospital, Osogbo, Osun State, Nigeria; Ph: +2348037251893; E-mail: lajidea@yahoo.com

Received: 26 December 2012

Accepted: 15 May 2013

Published: 01 September 2013 avoiding some of the cumbersome modalities earlier reported.

Keywords: Entrapment, Strangulation, Penile

$* * * * * * * * *$

Olajide AO, Eziyi AK, Olajide FO, Beyioku BK. Novel surgical extrication of penile constricting metal ring: A case report. International Journal of Case Reports and Images 2013;4(9):511-514.

$* * * * * * * * *$

doi:10.5348/ijcri-2013-09-368-CR-12

\section{INTRODUCTION}

Penile entrapment with strangulation is a rare clinical entity requiring urgent decompression [1]. Entrapping object is usually applied when penis is flaccid or semierect. It becomes impossible to remove when penis becomes erect leading to swelling of the penis distal to the object [2]. The management of this condition poses unique challenges to the treating physician through variable presentation as well as lack of specific treatment options. No standard treatment modality is described in literature; every case needs an individual approach depending upon the circumstances and facilities available [3]. Therefore, penile entrapment remains a challenge occasionally faced by urologists; it is tasking and requires ingenuity for successful treatment [4].

Methods described in literature include aspiration of corpora, use of saws, grinders, bolt cutters, and dental drills. Others include denudation of penile skin with postoperative skin grafting, amputation or use of myofascial flap for reconstruction of penis [3].

We report this case to illustrate a surgical technique used in the management of a penile entrapment with successful outcome. 


\section{CASE REPORT}

A 16-year-old boy presented in accident and emergency department with 4 days history of entrapment of his penile shaft in a steel ball bearing which he has used for erotic purpose. The ring had slipped in easily and entrapped after penile erection with failure of all attempts to remove the metal ring. He did not seek any help until four days. Later when he reported to relatives who made several attempts at remove the metal ring including use of metal cutting saws with no success. Urine stream has reduced progressively with increasing straining at micturition.

On examination, stainless steel ring of about $1.5 \mathrm{~cm}$ width impacted at the base of the penile shaft with marked swelling of the penile shaft distal to the metal ring and two areas of dark discolorations were noted on the penile skin (Figure 1). Sensory sensations were preserved on the penile shaft but arterial pulsation was not palpable. Initial attempts by lubrication and gentle traction on ring were unsuccessful following which he was transferred to the operating room. After failure of Gigli, orthopedic and metal cutting saws, he was given general anesthesia through a face mask, a transverse circumcising incision was made just proximal to the coronal sulcus, and this was extended vertically on the midline of the ventral surface of the penis. This incision was deepened to the sub-dartos plane, skin and dartos layer were subsequently raised off the Buck's fascia. Fluid with blood oozed out of the subcutaneous tissue with swelling of skin and subcutaneous tissue observed to reduce immediately. The skin and subcutaneous tissue then slid easily under the metal ring (Figure 2), followed by the erectile tissue contained within the Buck's fascia (Figure 3). Following removal of the metal ring, the skin was closed in single layer using nylon 3-O suture (Figure 4). Size 14 Foley's catheter was passed and left in place for 48 hours.

Postoperative period was uneventful and he was discharged and sutures were removed on 4th and 8th

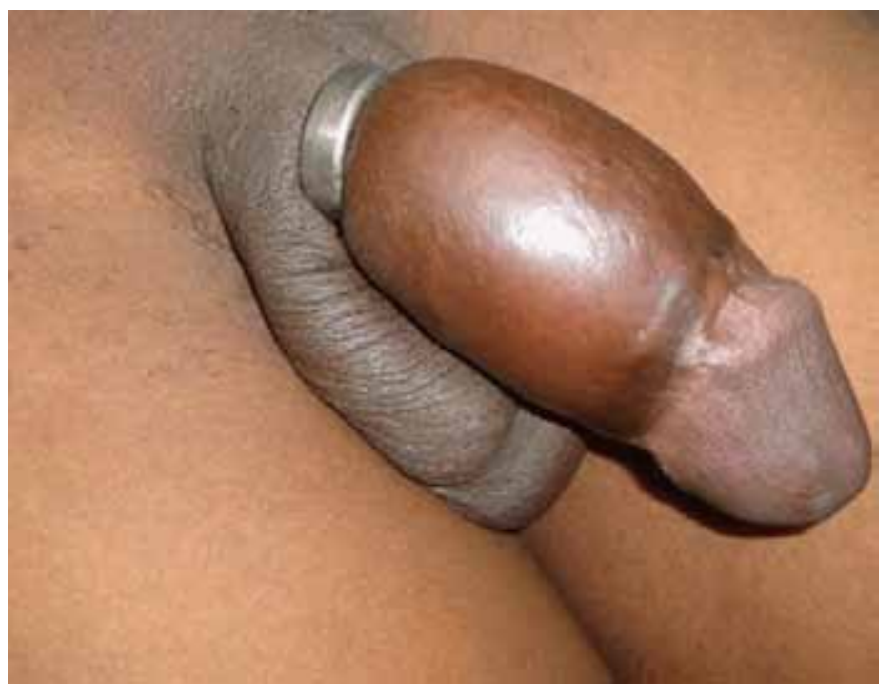

Figure 1: Preoperative picture showing entrapment and strangulation of penile shaft in the metal ring. postoperative days, respectively. The skin recovered completely and there was no complaint with urination and erection thereafter (Figure 5). He attended clinic for five months and lost to follow-up thereafter.

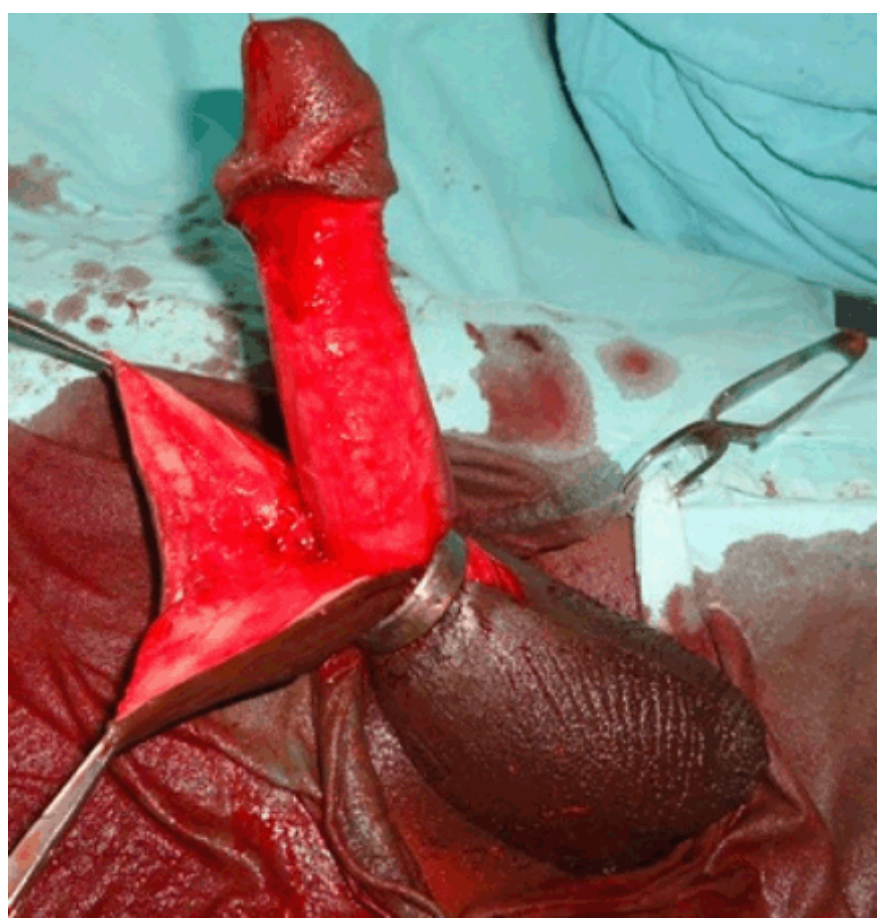

Figure 2: Reduction of swelling with sliding of skin and subcutaneous tissue under metal ring after penile degloving.

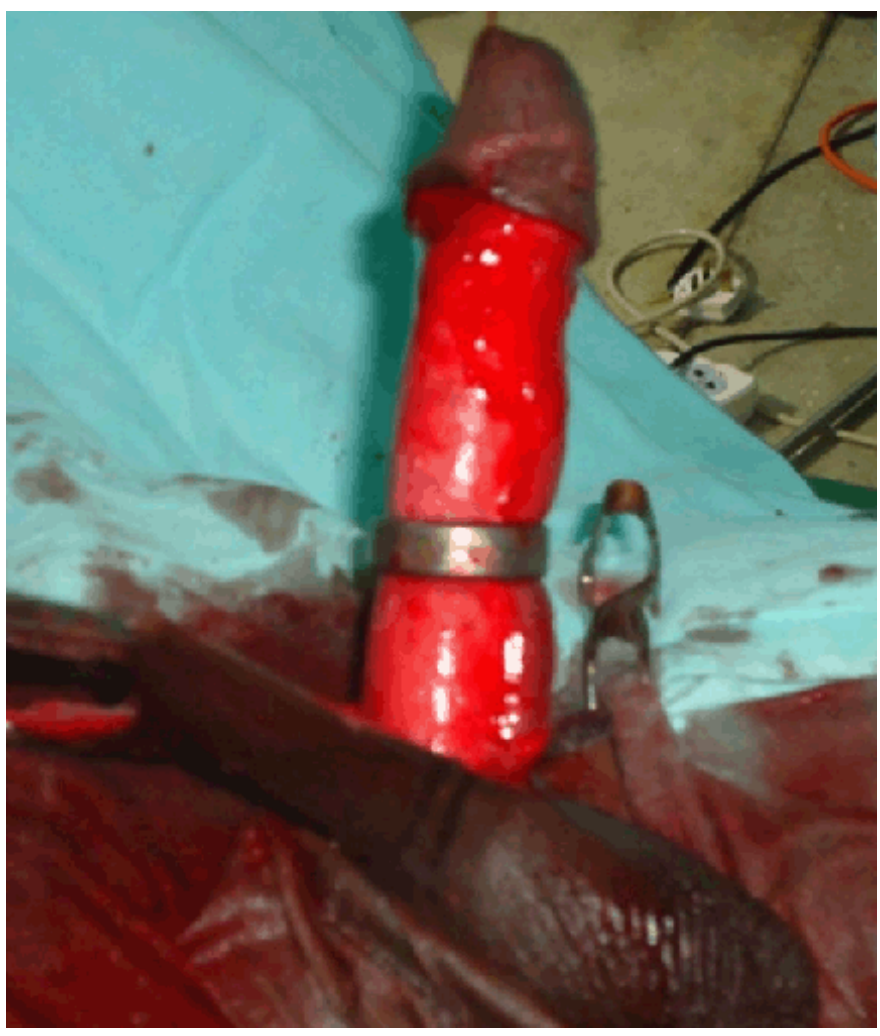

Figure 3: Metal ring on the erectile tissue after releasing the skin and subcutaneous tissue from under the metal ring. 


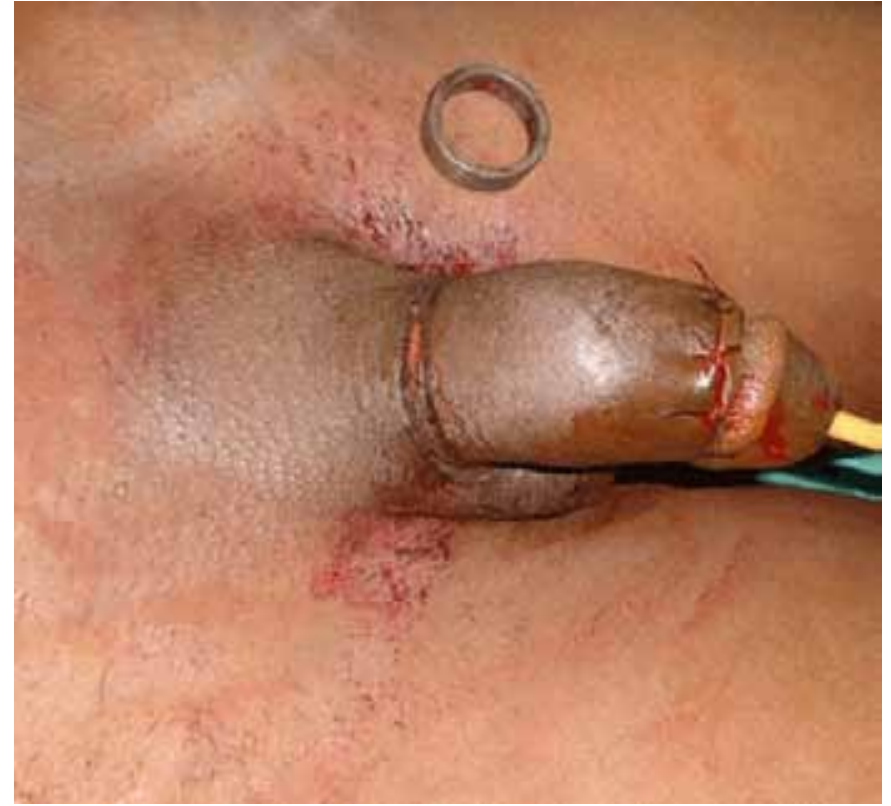

Figure 4: Immediate postoperative picture of penile shaft and the metal ring after extrication.

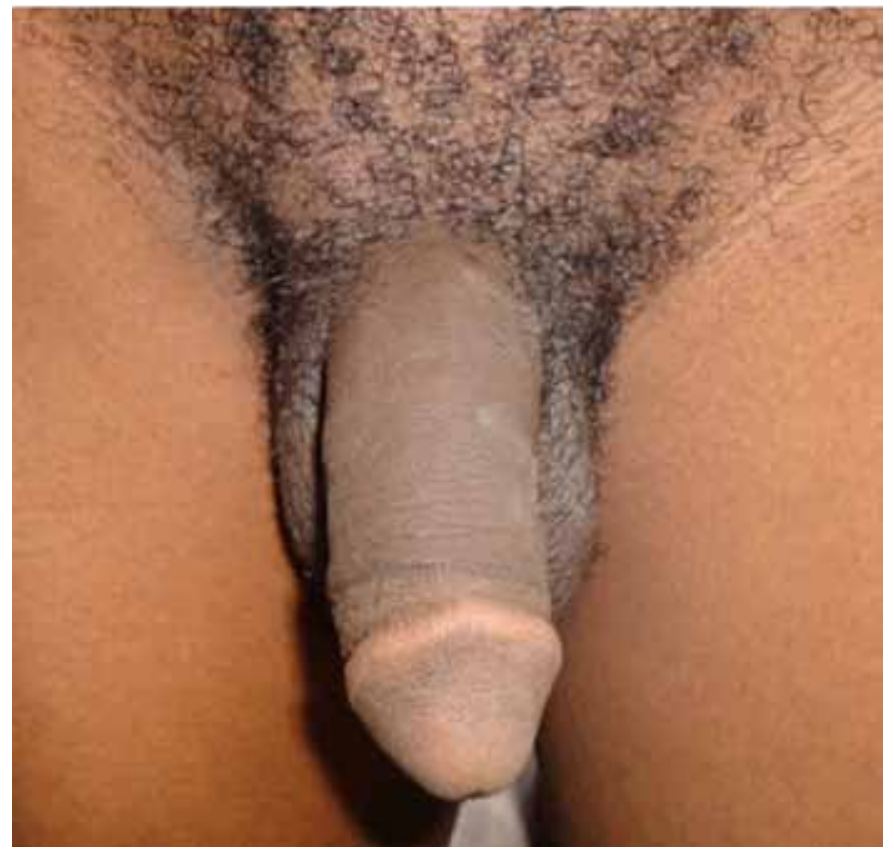

Figure 5: Picture of penile shaft three months after the surgery.

\section{DISCUSSION}

Though rare, penile entrapment can be associated with serious complications. It causes blockage of the venous return resulting in swelling of the penile skin and subcutaneous tissue distal to the object. Delay in treatment results in penile strangulation with ischemic necrosis and gangrene of the tissue [5].
Treatment requires urgent removal of the offending device and decompression of edema to prevent ischemic injury to the affected tissues. Various methods for removal of the various constricting devices have been documented in literature, these often involves consultation of various services, including emergency services to obtain special instruments to remove the constricting object [3, 6-9]. Most authors have canvassed for a multi-disciplinary approach including the assistance of jewelers and locksmiths and fire department to procure appropriate tools for removal [1]. A few surgical techniques have also been described including winding of silk from the glans, string techniques and aspiration of corpora tissue $[5,10]$. None of these methods is considered a standard modality of treatment; each case needs an individual approach depending upon the encircling material, assessment of severity and available facilities and tools [3].

The method presented in this report is applicable and successful because the swelling in penile entrapment is due mainly to venous engorgement resulting in swelling mostly in the skin and the subcutaneous fascia (dartos) which is loosely attached to the underlying Buck's fascia. In addition, thickness of Buck's fascia and corporeal tissue resist pressure on the deep vessels, avoiding gangrene of the erectile bodies [3]. These facts allow for easy elevation of the penile covering over Buck's fascia and its content (degloving). As soon as degloving started, fluid and blood was observed to egress from the subcutaneous tissues with immediate reduction of the swelling of the penile skin and subcutaneous tissue. This gave space for skin and subcutaneous tissue to slide under the constricting ring first and the penile shaft thereafter.

This procedure is simple, purely surgical and not new to most urologists because it is part of some forms of urethroplasty for hypospadias and urethral stricture. It obviates need for any special instrument and further delay in waiting for fire fighters, jewelers or locksmiths.

\section{CONCLUSION}

Penile entrapment and strangulation remains a rare challenge to urologist worldwide with need for emergency decompression to prevent grave complications. Simple degloving of the penis reduces the swelling and allows easy removal of the constricting object.

\section{$* * * * * * * * *$}

\section{Author Contributions}

Abimbola Olaniyi Olajide - Conception and design, Acquisition of data, Drafting the article, Final approval of the version to be published

Amogu Kalu Eziyi - Conception and design, Critical revision of the article, Final approval of the version to be published 
Folakemi Olajumoke Olajide - Drafting the article, Critical revision of the article, Final approval of the version to be published

Babatunde Kazeem Beyioku - Acquisition of data, Final approval of the version to be published

\section{Guarantor}

The corresponding author is the guarantor of submission.

\section{Conflict of Interest}

Authors declare no conflict of interest.

\section{Copyright}

(C) Abimbola Olaniyi Olajide et al. 2013; This article is distributed under the terms of Creative Commons attribution 3.0 License which permits unrestricted use, distribution and reproduction in any means provided the original authors and original publisher are properly credited. (Please see www.ijcasereportsandimages.com/ copyright-policy.php for more information.)

\section{ACKNOWLEDGEMENTS}

We wish to acknowledge the Ms Funmlayo Atoyebi and Dr Damola Tanimowo, the perioperative nurse and anesthesiologist who supported us in the operating room during the surgery.

\section{REFERENCES}

1. Eaton SH, Dickstein RJ, Wiygul JB. Novel use of the Gigli saw for management of penile entrapment. J Sex Med 2009;6(2):595-7.

2. Perabo FG, Steiner G, Albers P, Müller SC. reatment of penile strangulation caused by constricting devices. Urology 2002;59(1):137.

3. Ivanovski O, Stankov O, Kuzmanoski M, et al. Penile strangulation: Two case reports and review of the literature. J Sex Med 2007;4(6):1775-80.

4. Patel C, Kim R, Delterzo M, Wang R. Prolonged penile strangulation with metal clamps. Asian J Androl 2006;8(1):105-6.

5. Noh J, Kang TW, Heo T, Kwon DD, Park K, Ryu SB. Penile Strangulation Treated With The Modified String Method. Urology 2004;64(3):591.

6. Sathesh-Kumar T, Hanna-Jumma S, De'zoysa N, Saleemi A. Genitalia strangulation-Fireman to the rescue! Ann R Coll Surg Engl 2009;91(4):W15-6.

7. Silberstein J, Grabowski J, Lakin C, Goldstein I. Penile constriction devices: Case report, review of the literature, and recommendations for extrication. J Sex Med 2008;5(7):1747-57.

8. Kang SP, Chakravarti A, Amer K. Help of the fire brigade in a case of a strangulated penis. Ann R Coll Surg Engl 2001;83(1):49.

9. Kore RN, Blacklock AR. Ring the fire brigade. Br J Urol 1996;78(6):948.

10. Vahasarja VJ, Hellstrom PA, Serlo W, Kontturi MJ. Treatment of penile incarceration by the string method: 2 case reports. J Urol 1993;149(2):372-3.
Access full text article on other devices

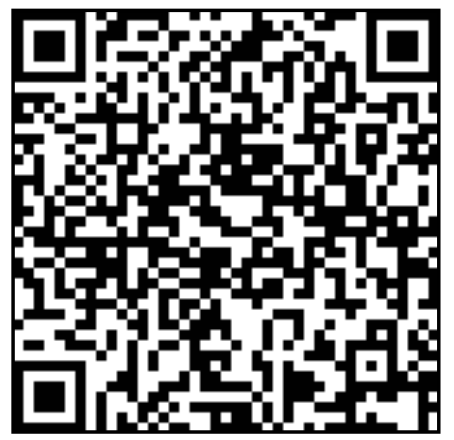

Access PDF of article on other devices

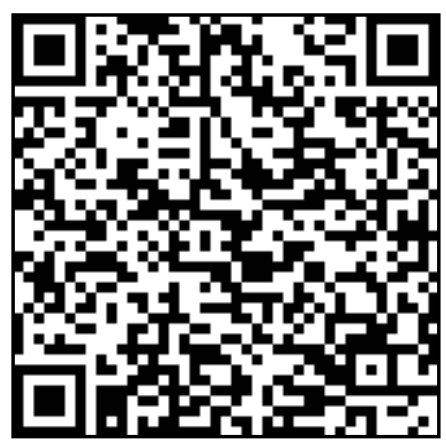

